\title{
Effects of different levels and sources of zinc on dry matter production and nutrient uptake by cotton (Gossypium hirsutum L.) in salt affected soil
}

\section{S. SATHIYAMURTHI AND K. DHANASEKARAN}

Received : 04.09.2014; Revised : 03.10.2014; Accepted : 20.10 .2014

\author{
MEMBERS OF RESEARCH FORUM \\ Corresponding author : \\ S. SATHIYAMURTHI, Department of \\ Soil Science and Agricultural \\ Chemistry, Faculty of Agriculture, \\ Annamalai University, \\ Annamalainagar, CHIDAMBARAM \\ (T.N.) INDIA \\ Co-authors : \\ K. DHANASEKARAN, Department of \\ Soil Science and Agricultural \\ Chemistry, Faculty of Agriculture, \\ Annamalai University, \\ Annamalainagar, CHIDAMBARAM \\ (T.N.) INDIA
}

\begin{abstract}
Summary
The present study was aimed to study the effects of different zinc levels and sources on nutrient availability of cotton in saline sodic soil. A pot experiment was conducted in Factorial Completely Randomized Design with three replications. The treatments consisted of three different sources of zinc namely zinc sulphate, zinc-EDTA and zinc humate and four levels of $\mathrm{Zn}\left(0,1.25,2.5\right.$ and $\left.5.0 \mathrm{mg} \mathrm{kg}^{-1}\right)$. Cotton variety MCU-7 was grown as test crop. The dry matter production (DMP) and Zn uptake at different stages of crop growth were recorded in each pot separately. The uptake of NPK was recorded at harvest. The results of the study indicated that soil application of $\mathrm{Zn}$ significantly increased the dry matter production of the cotton invariably at all stages of crop growth. Among the three sources, Zn-humate recorded the highest DMP when compared with other two sources. Increasing the levels of $\mathrm{Zn}\left(0\right.$ to $\left.5.0 \mathrm{mg} \mathrm{kg}^{-1}\right)$ significantly increased the uptake of nitrogen, potassium and $\mathrm{Zn}$. But phosphorus uptake by cotton was increased upto $2.5 \mathrm{mg} \mathrm{kg}^{-1}$ of $\mathrm{Zn}$. Beyond that level, significant reduction in phosphorus uptake was observed. The present study concluded that $2.5 \mathrm{mg} \mathrm{kg}^{-1} \mathrm{of} \mathrm{Zn}$ through zinc humate is the optimum dose for highest dry matter production and maximum NPK and $\mathrm{Zn}$ uptake.
\end{abstract}

Key words : Cotton, Dry matter production, NPK uptake, Salt affected soil, Zn-EDTA, ZnSO ${ }_{4}$, Zinc humate, Zinc uptake

How to cite this article : Sathiyamurthi, S. and Dhanasekaran, K. (2014). Effects of different levels and sources of zinc on dry matter production and nutrient uptake by cotton (Gossypium hirsutum L.) in salt affected soil. Asian J. Soil Sci., 9(2): 208-212. 